\title{
A PRODUÇÃO DE COMENTÁRIOS CRÍTICOS EM CONTEXTO DE SALA DE AULA INVERTIDA (FLIPPED CLASSROOM): UMA PROPOSTA PARA O ENSINO DE LÍNGUA PORTUGUESA NO ENSINO FUNDAMENTAL
}

Gustavo Gomes Siqueira da Rocha Luciana Teixeira 
Rocha, Gustavo Gomes Siqueira da.

A produção de comentários críticos em contexto de Sala de Aula Invertida (Flipped Classroom): : uma proposta para o ensino de Língua Portuguesa no Ensino Fundamental / Gustavo Gomes Siqueira da Rocha. -- 2021.

$36 \mathrm{f}$ : : il.

Orientadora: Luciana Teixeira

Dissertação (mestrado profissional) - Universidade Federal de Juiz de Fora, Faculdade de Letras. Programa de Pós-Graduação em Letras, 2021.

1. Sala de Aula Invertida. 2. Análise da Conversa Etnometodológica. 3. Comentário Crítico. 4. Metodologias Ativas. I. Teixeira, Luciana, orient. II. Título. 


\title{
Ficha técnica
}

\author{
Organizadores
}

Elza de Sá Nogueira

Érika Kelmer Mathias

Luciana Teixeira

Marco Aurélio de Sousa Mendes

Natália Sathler Sigiliano

Patrícia Pedrosa Botelho

Thais Fernandes Sampaio 
Universidade Federal de Juiz de Fora

Mestrado Profissional em Letras

2021 


\section{Apresentação da Coleção de Cadernos Pedagógicos}

\section{PROFLETRAS/UFJF 2021}

Érika Kelmer Mathias

Natália Sathler Sigiliano

O mestrado profissional em Letras da Universidade Federal de Juiz de Fora tem assumido, desde a sua constituição, em 2013, o compromisso de um trabalho desenvolvido em prol da capacitação de professores de Língua Portuguesa da rede básica de ensino fundamental, o que tem contribuído para a melhoria da qualidade de ensino da região e do país.

Como uma maneira de formar professores em seu próprio campo de atuação, assim como de impactar professores fora do programa - a quem seja possível o acesso ao conhecimento das práticas de pesquisas realizadas -, a elaboração de produtos educacionais de ensino é inserida como requisito básico da formação dos professores que ingressam nesse mestrado. Desde 2013, esse trabalho esteve integrado à realização de uma prática pedagógica interventiva inserida no contexto de sala de aula em que o professor, agora também pesquisador, atuava.

No ano de 2020, um cenário educacional atípico se revelou em todo o Brasil - e no mundo - devido à pandemia provocada pelo novo coronavírus. Nesse ano, diversos alunos da Turma 6 do PROFLETRAS da UFJF já haviam iniciado, em fevereiro de 2020, a aplicação de suas propostas de intervenção em salas de aula presenciais, e outros tinham planos de fazê-lo ainda nos primeiros meses do mesmo ano. No entanto, como forma de assegurar a saúde dos diversos atores envolvidos na esfera escolar, as aulas presenciais precisaram ser subitamente interrompidas, no país, ao longo do mês de março de 2020. Diante dessa realidade, enquanto as redes privadas puderam rapidamente adotar ações no sentido de implementar um ensino remoto emergencial, adquirindo dispositivos, softwares e programas específicos, as redes públicas só conseguiram iniciar as atividades remotas meses 
depois do início da suspensão das aulas presenciais. Em alguns estados e municípios, o ensino remoto emergencial só se iniciou no segundo semestre de 2020. Nesse sentido, o impacto nas pesquisas em curso no programa foi muito forte, não somente em função do intervalo de contato entre o professor-pesquisador e sua turma de atuação, como, principalmente, diante do novo cenário com o ensino remoto, cujas ações foram aplicadas de formas diferentes por estados e municípios: aulas remotas síncronas através de plataformas e/ou aplicativos de mensagens; aulas remotas assíncronas através de plataformas, TVs, material impresso e entregue aos alunos; materiais didáticos organizados pelas redes de ensino, sem a participação do professor; materiais criados e/ou adaptados pelos professores em seus anos e turmas de atuação; além de outras modalidades.

Dessa maneira, sensível a esse contexto, a coordenação nacional do mestrado profissional em Letras, por meio da resolução $n^{\circ}$ 003/2020, em 02 de junho de 2020, autorizou, de forma inédita, a possibilidade de serem realizadas, no âmbito do programa, propostas de ensino que não necessariamente tivessem caráter interventivo.

Diante disso, a Turma 6 do PROFLETRAS da UFJF colocou-se o desafio de realizar - ou de continuar a realizar - pesquisas as quais, mesmo em um contexto de muita apreensão e angústia quanto à vida e ao trabalho, resultaram em um conjunto de Cadernos Pedagógicos que apresentam características diversificadas quanto à situação de elaboração: alguns deles foram aplicados, mesmo em meio a um cenário atípico de aulas remotas; outros se compuseram de propostas de ações e atividades cujas aplicações poderão ser desenvolvidas futuramente.

É importante destacar também que, assim como todo texto que se constrói em interação com seus leitores, a constituição desses produtos pedagógicos contou - e contará - com uma rede de colaboração de diversos atores: professores e orientadores do programa, professores-discentes do mestrado profissional, professores participantes de bancas de qualificação e defesa, professores-colegas dos discentes do programa, alunos da rede básica que se propuseram a fazer parte das pesquisas e, ainda, professores que poderão conhecer, analisar, modificar e empregar estratégias inspiradas, em alguma medida, por aquelas aqui apresentadas por meio desta coleção. 
Todos os Cadernos Pedagógicos tiveram como escopo a ideia de que "a especificidade da formação pedagógica, tanto a inicial como a contínua, não é refletir sobre o que se vai fazer, nem sobre o que se deve fazer, mas sobre o que se faz" (HOUSSAYE, 1995, p.28), no desejo de que esse pensamento guie não somente os autores, mas também os futuros leitores desses Cadernos a reflexões e ações sobre seus próprios fazeres pedagógicos.

É nessa esteira que, mais uma vez, apesar de todos os percalços do momento atual na educação, os Cadernos Pedagógicos produzidos no âmbito do PROFLETRAS/UFJF trazem propostas autorais e inovadoras de ensino de Língua Portuguesa e Literatura, revelando forte compromisso por parte dos professores envolvidos em sua produção com o ensino público de qualidade. 


\section{Apresentação do projeto}

\section{Caro Professor,}

Você está sendo apresentado a um caderno pedagógico elaborado a partir de reflexões sobre o uso de metodologias ativas no contexto da educação básica; em termos mais específicos, a Sala de Aula Invertida (do inglês, Flipped Classroom, (cf. BERGMANN; SAMS, 2016), em que o professor desempenha o papel de mediador no processo de ensino/aprendizagem. O escopo norteador desta proposta focaliza o trabalho com o gênero textual comentário crítico, realizado com uma turma do $7^{\circ}$ ano do Ensino Fundamental de uma escola da rede estadual de Minas Gerais.

A perspectiva teórico-metodológica que se assume no desenvolvimento deste projeto interventivo rompe, em certa medida, com a sala de aula tradicional, pautada na transmissão de conhecimentos do professor para o aluno, muitas vezes marcada pelo preconceito linguístico e cultural, e se volta a uma prática educativa colaborativa, que permita a troca de saberes entre os sujeitos envolvidos e valorize o diálogo, o respeito e as habilidades de cada um.

De acordo com a proposta da Sala de Aula Invertida, viabiliza-se aos alunos conhecimento prévio acerca de determinado conteúdo por meio de material fornecido com antecedência pelo professor. Os alunos podem recorrer a videoaulas, games, slides, ebooks, aplicativos ou qualquer outro material complementar que potencialize o processo de aprendizagem de forma dinâmica e inovadora, sempre com a supervisão de um tutor, para esclarecer dúvidas ou qualquer outra demanda que possa ocorrer. Com isso, ao tempo offline alia-se o tempo presencial (no caso do ensino remoto, ao tempo assíncrono alia-se o tempo síncrono), pois a aula (presencial ou síncrona) pode ser dedicada a desenvolver os assuntos mais importantes. Na Sala de Aula Invertida, o tempo em classe é utilizado para aprofundar temas, criar oportunidades de aprendizagem mais enriquecedoras e maximizar as interações face a face, com o objetivo de garantir a compreensão e a síntese do conteúdo trabalhado.

É válido ressaltar que o projeto interventivo que aqui se apresenta tem caráter propositivo, devido ao fato de esta pesquisa ter se desenvolvido durante $\circ$ ensino remoto, vigente no período de distanciamento social, em razão da 
emergência sanitária ocasionada pela pandemia da COVID-19. A Sequência Didática (SD) foi pensada para ser aplicada a uma turma de $7^{\circ}$ ano do segundo segmento do Ensino Fundamental, conforme se mencionou na abertura desta seção; no entanto, sugere-se que você, professor, possa adaptá-la e aplicá-la a outras séries.

A proposta de projeto interventivo está definida da seguinte maneira:

produção inicial não modelar, isto é, sem o aluno conhecer o texto modelar, aplicada de maneira remota durante o ano letivo de 2020; etapa 1, com 2 aulas, com o intuito de orientar uma pesquisa sobre a vida da protagonista do livro "Eu sou Malala", de Malala Yousafzai; etapa 2, com 2 aulas, tendo em vista o trabalho mais específico com adjetivos; etapa 3, com 2 aulas, que visam a abordar a estrutura da argumentação e diferenciar fato de opinião; etapa 4 com 2 aulas, cuja finalidade é a de se trabalhar a estrutura do gênero comentário crítico; etapa 5, com 01 aula, cuja proposta é a elaboração colaborativa de um roteiro para a produção de comentários críticos; etapa 6, com 1 aula, cujo objetivo é o de realizar a produção e a avaliação de um novo comentário crítico e, finalmente, a proposta de produção final na etapa 7, com previsão de 1 aula.

Aproveite este material!

Clique aqui para baixar a dissertação 


\section{Sumário}

$\begin{array}{ll}\text { Começando a conversa } & 10\end{array}$

Etapa pré-interventiva: preparando o terreno 11

Etapa inicial: escrevendo o primeiro comentário sobre Malala Yousafzai 14

$\begin{array}{ll}\text { Etapa 1: pesquisando sobre Malala } & 18\end{array}$

Etapa 2: (re)conhecendo e usando adjetivos 21

Etapa 3: trabalhando a argumentação e diferenciando fato de opinião 25

Etapa 4: (re)conhecendo o comentário crítico 28

Etapa 5: elaborando um roteiro norteador 30

Etapa 6: escrevendo e avaliando um comentário 31

Etapa 7: produzindo uma seção cultural 33

$\begin{array}{ll}\text { Encerrando a conversa } & 34\end{array}$

Referências e sugestões de leitura $\quad 35$ 


\section{Começando a conversa}

O projeto interventivo delineado neste caderno pedagógico apresenta uma proposta de Sequência Didática (SD) com vistas a subsidiar a produção de comentários críticos acerca da biografia "Eu sou Malala", de Malala Yousafzai, através de aulas planejadas, conforme pressupostos da Sala de Aula Invertida.

Vale ressaltar que neste caderno pedagógico, utiliza-se o termo "etapas", que corresponde ao termo "módulos" utilizado na escrita da Dissertação, visando descrever os passos de aplicação da SD em questão.

A escolha da biografia "Eu Sou Malala" justifica-se por ser um livro paradidático constante da lista de obras indicadas para leitura pelos discentes da Escola Estadual Ilka Campos Vargas e escolhido pelos alunos, a partir de uma pré-seleção realizada por docentes da área de Linguagens, e disponível, em sua forma impressa, na biblioteca da escola, lócus desta pesquisa, bem como na Internet (Clique aqui para fazer o download da obra "Eu Sou Malala".), conforme ilustra a figura 1 a seguir:

Figura 1- "Eu Sou Malala"

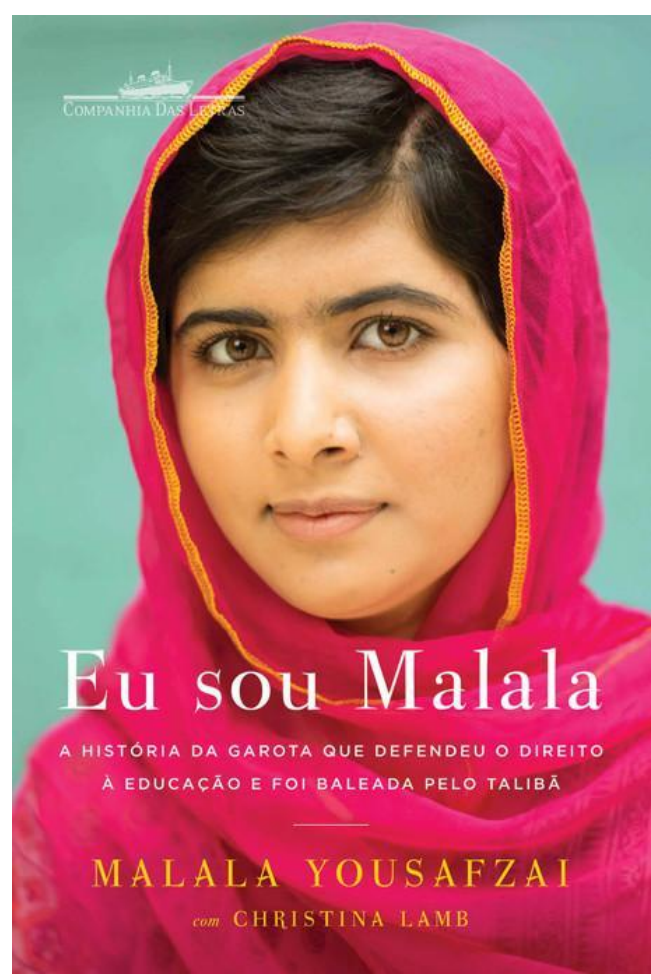

Fonte:

https://lelivros.love/book/download-eu-sou-malala-malala-yousafzai-em-epub-mobi-e-pdf/ 


\section{Etapa pré-interventiva: preparando o terreno}

Em uma etapa anterior ao início do período de ensino remoto, com os alunos ainda no $6^{\circ}$ ano em 2019, foi realizada uma atividade em caráter pré-interventivo, que consistiu na produção inicial de um comentário crítico, a partir da exibição de um curta-metragem da franquia Toy Story, intitulado Toy Story - Férias no Havaí, conforme ilustra a figura 2 a seguir:

Figura 2- Toy Story- Férias no Havaí

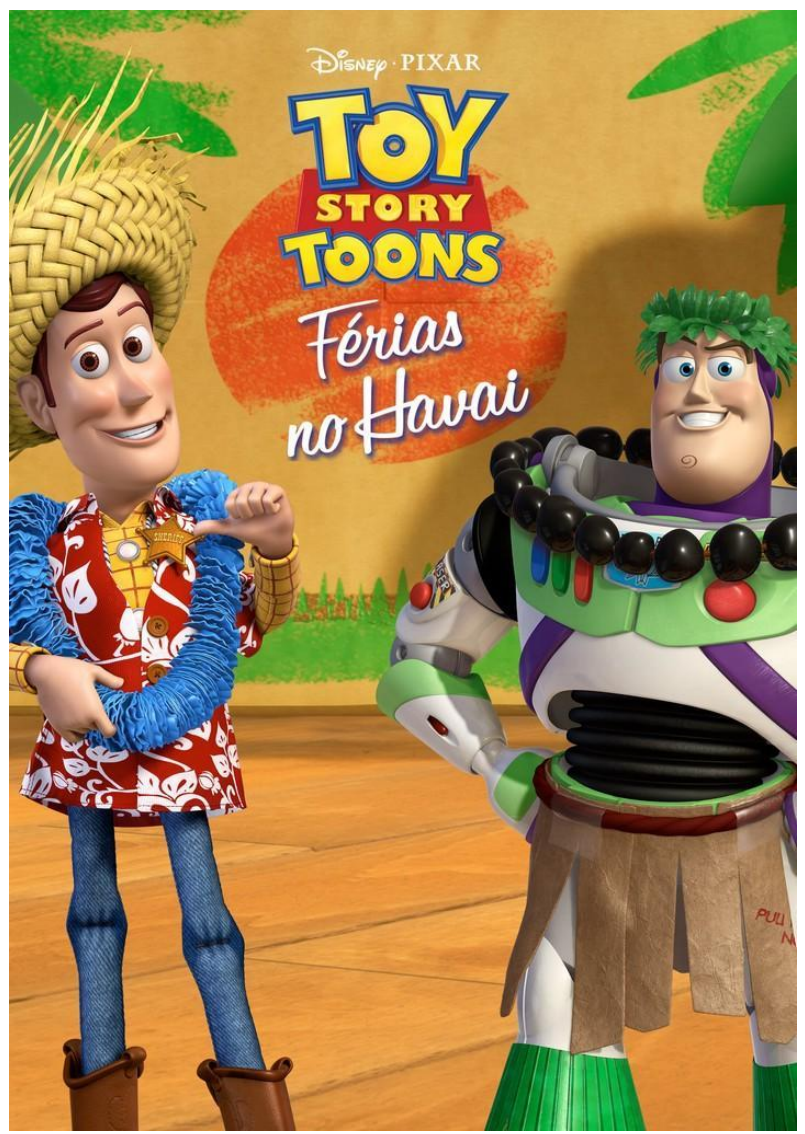

Fonte: https://www.youtube.com/watch?v=KTerctZvepM

A duração do curta Toy Story - Férias no Havaí, disponível aqui, é de cerca de 6 minutos, tendo sido acessado pelo professor-pesquisador através da plataforma YouTube, em uma SmarTV da sala de multimeios da escola e exibido aos alunos, que, em sua maior parte, já conhecia os filmes da franquia Toy Story, porém ainda não havia assistido ao curta em questão. Após a exibição do filme, o professor-pesquisador realizou algumas perguntas orais, tais como:

- O que você achou do curta? 
- Você já tinha assistido a algum filme do Toy Story antes?

- Qual o assunto principal do curta que acabamos de assistir?

Caso você, professor, tenha a intenção de realizar alguma atividade voltada para a produção de algum gênero textual, a partir desse curta-metragem, estimulando a criatividade de seus alunos, outras sugestões podem ser apresentadas à sua turma, como por exemplo: "Que outro final essa animação poderia ter?", ou ainda, "Se você pudesse escolher outro lugar para situar a história, onde seria?".

Voltando a descrever o procedimento da atividade aplicada, o professor explicou, então, a tarefa através da seguinte instrução: "Escreva um comentário falando sobre o curta, dizendo se gostou ou não do filme e justifique sua opinião". A imagem a seguir exemplifica uma das produções obtidas na etapa pré-interventiva:

Figura 3- Comentário 1 da etapa pré-interventiva

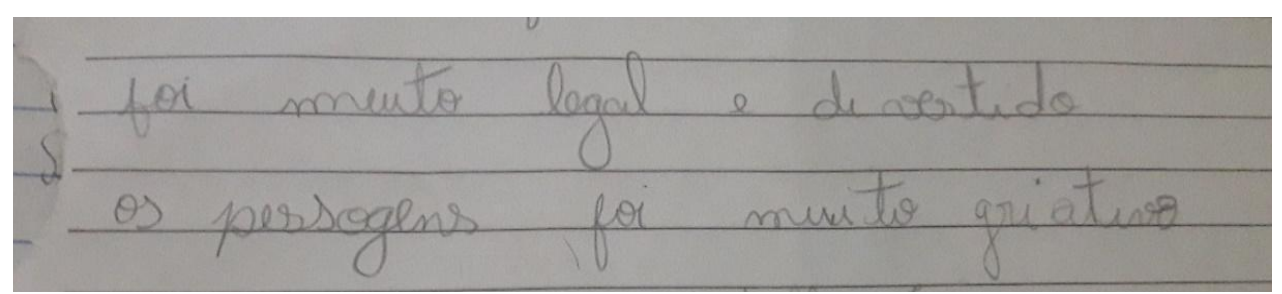

Fonte: Produção de um discente

Transcrição do excerto da Figura 3:

Foi muito legal e divertido. Os persogens [personagens] foi muito griativo [criativo].

Figura 4- Comentário 2 da etapa pré-interventiva

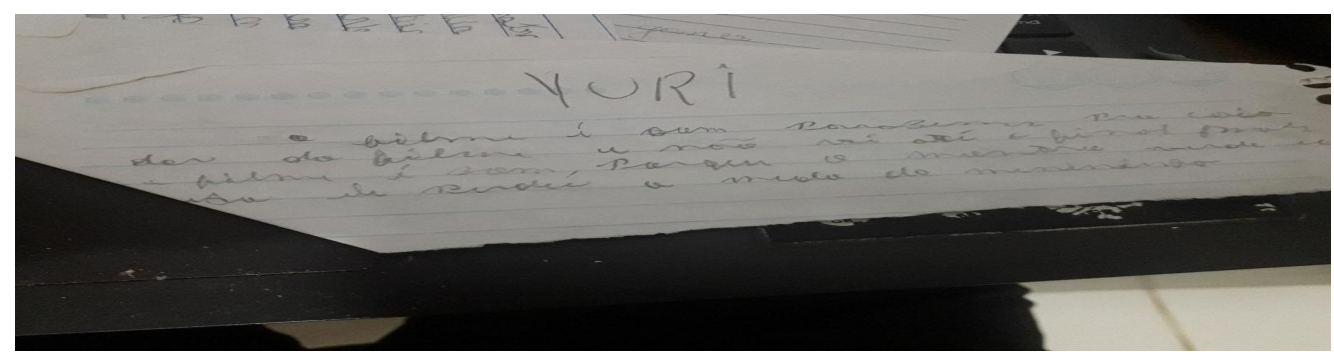

Transcrição do excerto da Figura 4: 
O filme é bom. Parabéns pro [para o] criador/ do filme eu não vi até o final mais [mas]/ o filme é bom porque o monstro verde/ ele perde o medo de menininho

Os textos produzidos no contexto da pré-intervenção foram corrigidos e, conforme se pode constatar pelos dois exemplos das figuras 3 e 4 acima, não atenderam a proposta de produção do gênero comentário crítico. Os alunos apresentaram uma breve apreciação crítica do curta, sem descrição das cenas ou caracterização dos personagens da obra, e sem fundamentar sua opinião, tendo sido observada a necessidade de um trabalho mais específico com adjetivos e com estratégias de argumentatividade. Para uma análise detalhada dos resultados, consultar seção 6.2 da Dissertação.

Dessa forma, a atividade pré-interventiva forneceu subsídios para que a intervenção fosse delineada de modo a minimizar as dificuldades verificadas. Foi um começo para a autoavaliação a respeito do modo como a atividade havia sido proposta. A orientação dada aos alunos para a produção do comentário reproduzia o modelo tradicional de aula, e a pergunta realizada não era suficientemente clara, além de não ter relação com o gênero textual pretendido, sem uma contextualização adequada em seu início, e sem menção à apreciação e à recomendação (ou não) do curta-metragem. Caso a atividade seja reaplicada, porém na perspectiva da Sala de Aula Invertida, será proposto aos alunos que assistam ao curta em um momento anterior à aula, assim como realizem uma pesquisa sobre o Havaí em sites da internet para que, em sala, possam compartilhar com seus pares as informações obtidas. Além disso, será solicitado que os discentes façam um levantamento, em sites especializados (como o Adorocinema), sobre comentários críticos diversos, observando sua construção, isto é, sua estrutura composicional, de modo a que possam produzir comentários mais contextualizados e de maneira mais ativa.

O docente que desejar aplicar esta atividade, igualmente poderá proceder a uma produção diagnóstica e, a partir da identificação das dificuldades de sua turma ao produzir esse gênero, poderá planejar atividades e estratégias de ensino de Língua Portuguesa, com vistas a ressignificar e reinventar sua prática, dividindo com seus alunos a construção do conhecimento sobre os possíveis usos da língua. 


\section{Etapa inicial: escrevendo o primeiro comentário sobre Malala Yousafzai}

A Sequência Didática aqui apresentada consiste na elaboração de um comentário crítico acerca da biografia "Eu sou Malala", de Malala Yousafzai. Trata-se de um livro paradidático selecionado da lista de livros indicados para leitura no ano letivo de 2020. Para estimular o interesse dos alunos pela leitura e torná-los mais participativos e integrados à proposta de trabalho, este pesquisador sugeriu que os estudantes escolhessem, a partir de uma pré-seleção realizada pelos docentes da área de Linguagens da escola, o livro que eles gostariam de ler. Além de estar disponível, em sua forma impressa, na biblioteca da escola onde esta pesquisa foi conduzida, ele também pode ser baixado da Internet, conforme indicado no link da Figura 1.

Nesse sentido, tendo os alunos finalizado a leitura da biografia cerca de um mês após o início do período de ensino remoto, passou-se à leitura de trechos da obra, durante as primeiras aulas síncronas, de acordo com a seleção sugerida pelos discentes em interação prévia com o professor-pesquisador, que reuniu trechos específicos da obra em um arquivo e os enviou aos alunos, por e-mail, com antecedência, para que pudessem reler e relembrar os aspectos mais relevantes do livro, a serem discutidos na aula dedicada à produção do comentário crítico. $\mathrm{A}$ seguir, é apresentado um exemplo com trechos que foram enviados aos alunos: 
Figura 5- Trechos da obra "Eu Sou Malala"

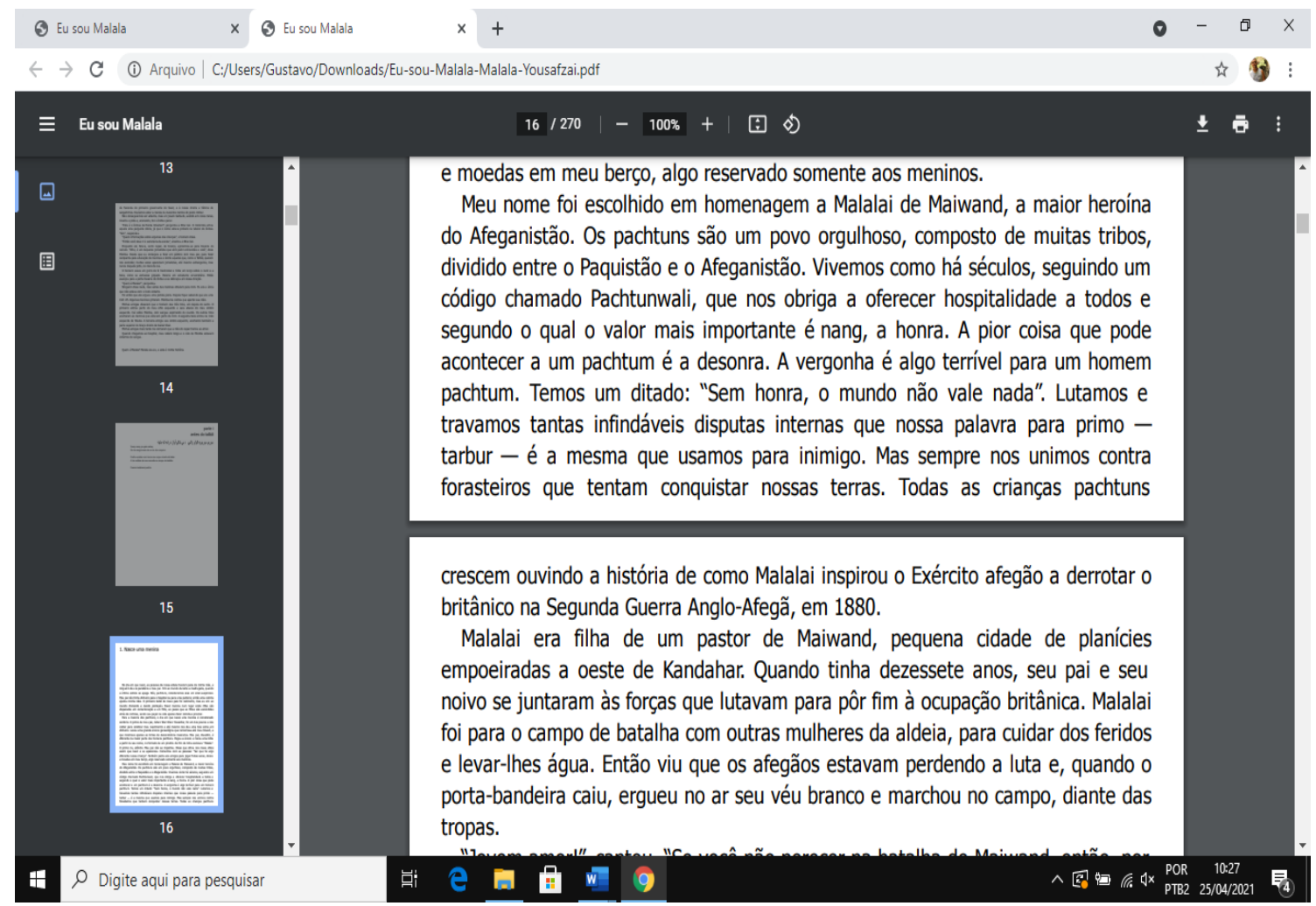

Fonte: Biografia "Eu Sou Malala"

Para mais exemplos de trechos enviados aos alunos, consultar Anexo C da Dissertação.

Dando prosseguimento ao trabalho da produção inicial, o docente, no momento síncrono, interagiu com os alunos de modo a identificar se eles haviam lido os trechos selecionados e enviou um vídeo (com duração de 1:22), intitulado "Mulheres Fantásticas - Malala Yousafzai", disponível para acesso aqui, conforme ilustra a figura a seguir: 
Figura 6- Vídeo "Mulheres Fantásticas- Malala Yousafzai"

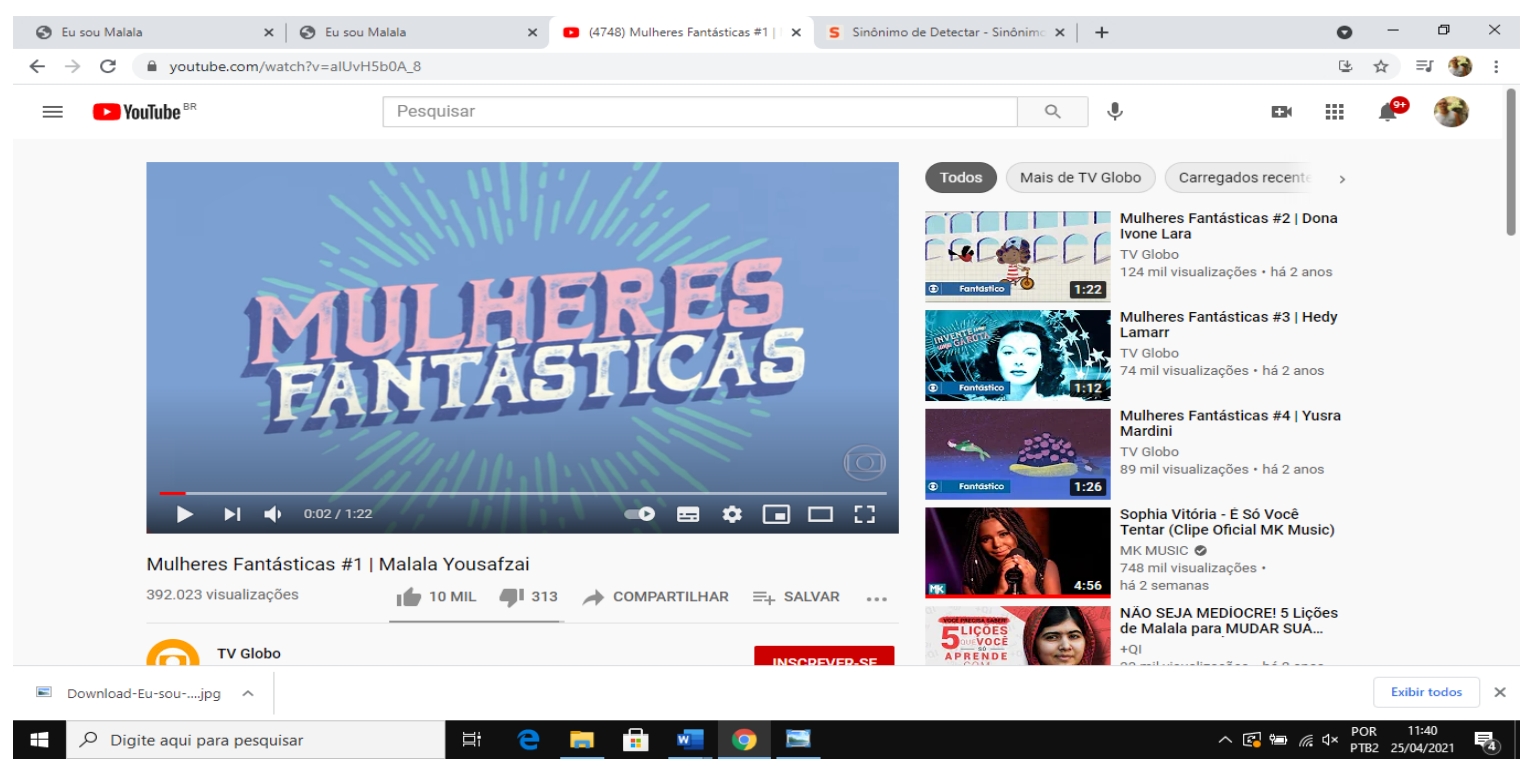

Fonte: https://www.youtube.com/watch?v=alUvH5b0A_8

Em seguida, o professor-pesquisador realizou duas perguntas visando verificar se os alunos haviam, de fato, assistido ao vídeo: "Qual nome Malala utilizou no e-mail para que sua identidade não fosse revelada?"; "Ter alterado a identidade deu certo para que ela não fosse descoberta?". Após a interação inicial, o docente prosseguiu para a realização dos comentários, tendo feito a seguinte proposta aos alunos: "Com base nos trechos que lemos nas aulas síncronas, escreva um comentário sobre a obra ‘Eu Sou Malala'. Justifique.” A expectativa era a de que o texto fosse estruturado nos moldes de um comentário crítico, pois esse gênero já havia sido trabalhado em 2019 com essa turma, por ocasião da exibição do curta da franquia Toy Story. Os alunos foram instruídos a justificarem suas respostas, a fim de se evitar que eles se limitassem a apenas dizer "gostei" ou "não gostei", tal qual fora constatado na pré-intervenção. Para detalhamento das etapas da aula, aplicada remotamente, consultar seção 6.4 da Dissertação.

Os textos produzidos estão transcritos a seguir:

TEXTO 1: Achei o livro muito chato porque a história é muito longa.

TEXTO 2: Legal, só que o motorista podia ter protegido a malala na hora que o menino deu um tiro nela. Até que eu gostei da história.

TEXTO 3: A menina é muito legal. Ela defende a educação para as meninas do seu país Eu gostei do livro.

TEXTO 4: Eu gostei da parte que ela fala que o nome dela é Malala por causa de uma heroína do país dela.

(Transcrição das produções escritas pelos alunos do $7^{\circ}$ ano) 
Foi observado que, apesar de os discentes já terem mantido contato prévio com o gênero, através de redes sociais e sites da internet, e até produzirem comentários com apreciações críticas frequentemente, ainda que de forma intuitiva, ao escreverem nessa etapa as produções textuais no gênero focalizado, demonstraram dificuldades em fundamentar sua crítica, limitando-se os comentários a uma apreciação superficial da história ou da protagonista, mas sem apresentar uma introdução, situando os principais eventos relatados e, em alguns casos, sem recomendar o livro ao final.

A partir das produções escritas nesta etapa inicial da intervenção, foi possível delinear os aspectos que deveriam ser trabalhados nas etapas subsequentes, tais como: ampliação do repertório lexical quanto ao uso de adjetivos; diferenciação de entre fato e opinião; identificação e uso de estratégias argumentativas e consolidação da estrutura de um comentário crítico. Para uma análise detalhada dos resultados da etapa inicial, consultar a seção 6.3 da Dissertação.

Propõe-se que o docente, leitor deste caderno pedagógico, solicite uma produção inicial de seus alunos de modo que consiga fazer um levantamento dos pontos em que precisará intervir, adaptando etapas e atividades da sequência didática, conforme as necessidades de seus discentes. Explorar aspectos da análise linguística, em interface com o trabalho ancorado em determinado gênero textual, como o comentário crítico, por exemplo, vai demandar do professor que ele saiba como tornar os alunos conscientes do conhecimento que já têm e do conhecimento que precisam alcançar para poder explicar os efeitos de sentido do uso, em textos, de estratégias de modalização (para realizar os comentários com polidez) e argumentatividade (para aprender a se posicionar e sustentar seus pontos de vista).

Nas etapas a seguir, são descritas as atividades propostas para a construção do conhecimento pelos alunos acerca do gênero textual escolhido como elemento central desta intervenção. 


\section{Etapa 1: pesquisando sobre Malala}

Com efeito, seguindo a proposta da Sala de Aula Invertida e partindo dos resultados obtidos na etapa inicial, era necessário que os alunos tivessem um papel mais ativo na construção de seu próprio conhecimento para elaboração de seus comentários críticos. Para alcançar esse propósito, na primeira aula da etapa 1, os discentes foram orientados a buscar informações, na Internet, a respeito de Malala e do atentado que ela sofrera, bem como da vida da menina e de sua família, após aquele terrível acontecimento.

Como tarefa, os alunos deveriam levar para a aula síncrona uma notícia, um documentário ou uma resenha da obra "Eu sou Malala", acompanhada de três perguntas acerca do material. Durante a aula eles responderam as perguntas que trouxeram.

Cabe ressaltar que, para a realização dessa etapa durante o momento síncrono, tendo sido a aula ministrada de maneira remota, os discentes foram orientados pelo professor-pesquisador sobre a maneira apropriada de se realizarem pesquisas em plataformas de buscas. Ele explicou que os alunos deveriam digitar apenas palavras-chave, além de serem breves e objetivos ao inserir palavras na barra de pesquisa.

Como resultado, os alunos compartilharam links sobre a protagonista do livro em estudo. Com efeito, os estudantes revelaram interesse por dois deles: (i) "Atentado contra Malala completa cinco anos: veja cinco conquistas da jovem que sobreviveu ao Talibã." (disponível aqui); (ii) "Uma criança, um professor, um livro e uma caneta podem mudar o mundo." (disponível aqui).

Este professor-pesquisador procurou tornar a atividade mais interativa, compartilhando o link de uma notícia sobre Malala Yousafzai, que pode ser acessada aqui, conforme ilustra a figura a seguir: 
Figura 7- Notícia "Malala se forma em Oxford"

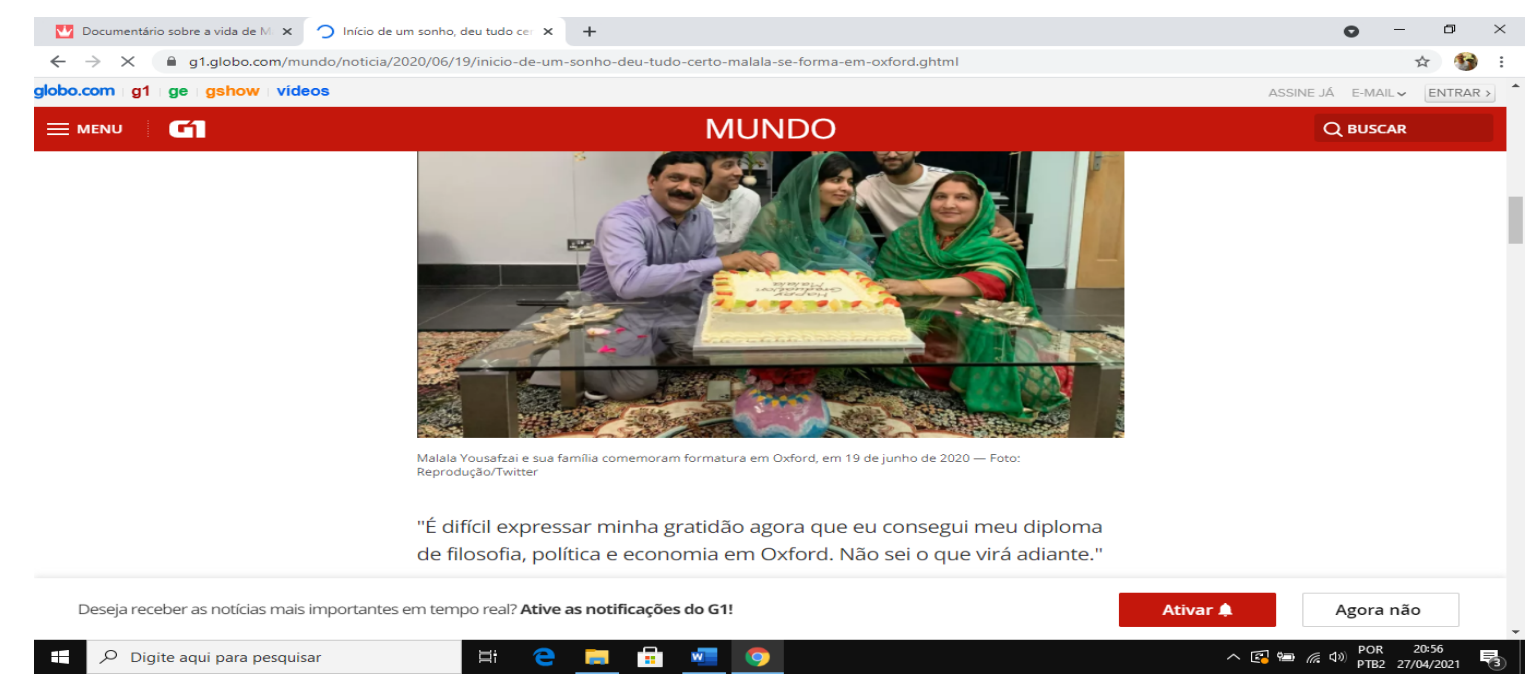

Fonte:

https://g1.globo.com/mundo/noticia/2020/06/19/inicio-de-um-sonho-deu-tudo-certo-malal a-se-forma-em-oxford.ghtml

O docente estimulou a realização de uma discussão a respeito do conteúdo desses links, sugerindo que os estudantes levassem, para a aula seguinte, mais uma notícia ou frase dita por Malala. Como resultado, um dos alunos lembrou a causa defendida por Malala, sintetizada na seguinte frase trazida por ele: "Nossos livros e nossos lápis são nossas melhores armas. A educação é a única solução, a educação em primeiro lugar".

O docente que desejar, poderá, também, realizar a etapa de pesquisa sobre aspectos da vida da jovem ativista e solicitar que os alunos, em casa, pesquisem uma notícia, um documentário ou resenha da obra "Eu sou Malala", acompanhada de três perguntas acerca do material. Durante a aula eles deverão responder, por escrito, as perguntas que trouxeram, para apresentar seus posicionamentos em uma roda de conversa (no caso do ensino on-line, essa roda de conversa pode ser adaptada por meio de plataformas como Google Meet, Zoom, Microsoft Teams, etc.).

A segunda aula da etapa 1 consiste na proposta de uso do recurso "Netflix Party", extensão oferecida pela plataforma de streaming Netflix, cujo intuito é criar uma sala compartilhada virtual, de modo que um grupo de pessoas possa assistir juntas ao mesmo filme, série ou documentário e interagir em tempo real através de um chat. No caso dessa aula, a turma deve assistir, de maneira compartilhada, ao documentário "Malala", dirigido por Davis Guggenheim. 
O professor que desejar acessar mais informações acerca do recurso Netflix Party, pode clicar aqui.

Figura 8- Trailer Oficial- Malala

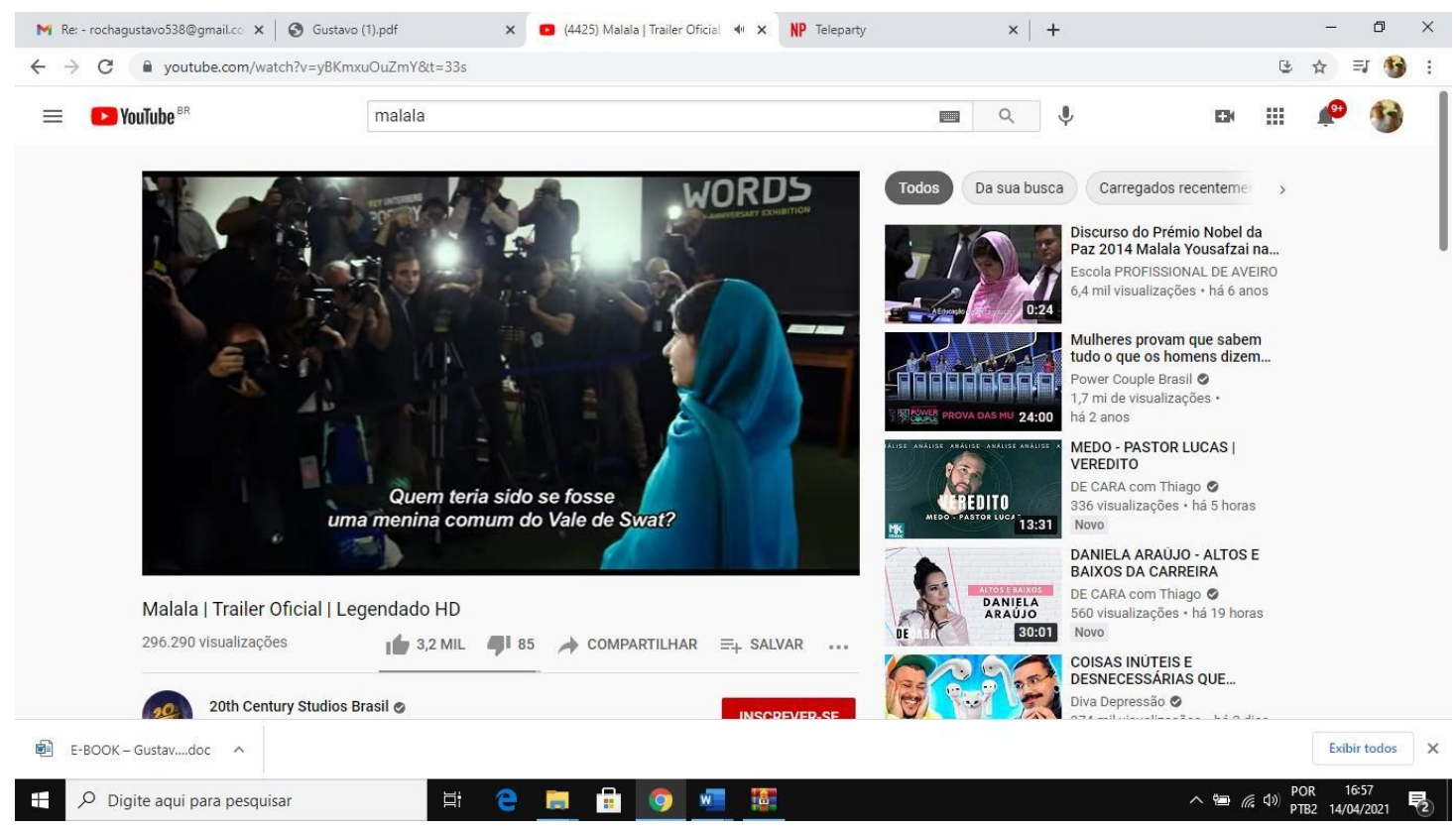

Fonte: https://www.youtube.com/watch?v=59YidU0ANQg

Assim sendo, posteriormente, sugere-se que o docente solicite que os alunos formulem três perguntas sobre fatos mostrados ao longo do documentário e se organizem em duplas, de tal modo que um responda, por escrito, a pergunta elaborada pelo parceiro e vice-versa, estimulando a aprendizagem colaborativa entre os discentes. Novamente cabe a proposta de os alunos, em encontro posterior, debaterem suas opiniões em uma roda de conversa, que poderá ser adaptada, no caso do ensino remoto, para transcorrer por meio de plataformas que disponibilizam várias ferramentas, as quais permitem a interatividade, como Zoom, Google Meet, Microsoft Teams, etc. 


\section{Etapa 2: (re)conhecendo e usando adjetivos}

A etapa 2, delineada em 2 aulas, visa desenvolver o repertório lexical, mais especificamente quanto ao uso de adjetivos, uma vez que o gênero comentário crítico demanda, por sua natureza avaliativa, o domínio por parte dos alunos do uso adequado de palavras que expressem caracterização.

Dessa maneira, a primeira aula desta etapa, será baseada no documentário "Malala", assistido através do recurso Netflix Party conforme explicitado na etapa 2. As atividades apresentadas a seguir buscam induzir o corpo discente a refletir acerca da forma como as pessoas e locais são descritos ao longo do documentário, de modo que o conceito sobre essa classe gramatical não seja apresentado em um primeiro momento:

1- A partir do documentário "Malala" exibido em aula, escreva três palavras que caracterizem a aparência física da ativista:

2- Com base nas informações do documentário, escreva três palavras que descrevam a personalidade de Malala:

3- Como as meninas do Vale do Swat são descritas no documentário?

4- Quais características de Malala a torna diferente das demais meninas?

5- Quais os sentimentos de Malala quanto a sua antiga terra?

6- Como Malala descreve o local em que ela morava? E a sua atual cidade?

7- Malala gosta da casa e da cidade onde ela mora atualmente?

8- Como você descreveria sua casa? E sua cidade?

Tomando como referência os princípios da Sala de Aula Invertida, para a aula 2 da etapa 2, em casa ou em um momento assíncrono, os alunos deverão assistir a uma videoaula que explicita a função e uso dos adjetivos, conforme indica a figura 9 a seguir, disponível aqui: 
Figura 9- Videoaula sobre adjetivos

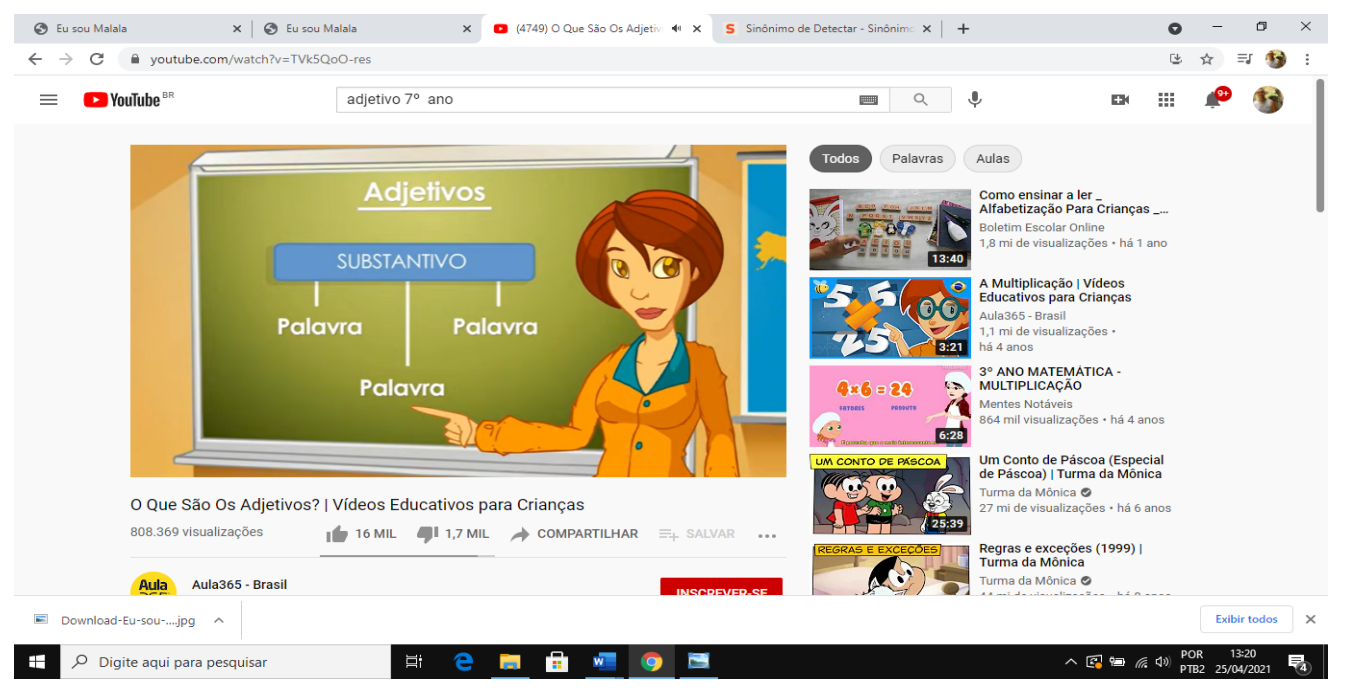

Fonte: https://www.youtube.com/watch?v=TVk5QoO-res

Em sala o professor pode proceder a uma discussão inicial acerca do conteúdo do vídeo assistido visando identificar as dúvidas que os alunos apresentem. Posteriormente, sugere-se o seguinte roteiro de perguntas, que tem como objetivo sistematizar o conhecimento sobre os adjetivos, contextualizando à obra "Eu Sou Malala" e consolidando o conhecimento adquirido na primeira aula deste módulo:

1- Na página 10 de sua biografia, Malala descreve seu quarto dizendo: "Hoje, quando abro os olhos de manhã, anseio por ver meu velho quarto, com as minhas coisas, as roupas todas no chão e os troféus que ganhei na escola nas prateleiras." Com base na descrição apresentada, escreva dois adjetivos que caracterizem o antigo quarto de Malala, e dois adjetivos que exprimam o sentimento da protagonista:

2- Também na página 10, a ativista apresenta uma breve descrição sobre Londres, sua atual cidade, dizendo: "Quando me ponho à frente da janela e observo a paisagem, vejo edifícios altos, longas avenidas cheias de carros movendo-se em filas organizadas, gramados bem cuidados e calçadas limpas por onde caminhar." Baseando-se nas palavras de Malala, escreva dois adjetivos que descrevam a cidade:

3- Para cada um dos trechos a seguir, identifique pelo menos 1 adjetivo: 
a- "Mas seu gabinete foi composto pelas velhas figuras de sempre. Mais uma vez nossa nação foi expulsa da Commonwealth e se tornou uma ovelha negra internacional." (p. 60)

b- "Minha mãe é muito bonita, e meu pai a adora. Trata-a como a um vaso de porcelana chinesa muito frágil, sem jamais encostar-lhe um dedo, ao contrário de como a maioria dos pachtuns trata as mulheres. O nome dela, Tor Pekai, significa "tranças negras", embora seu cabelo seja castanho." (p. 21)

4- Substitua, em cada uma das sentenças a seguir, retiradas da biografia "Eu Sou Malala", os adjetivos em destaque por um sinônimo.

a- "O primo riu, atônito" (p. 16)

b- "Nós nos despedimos dele e ficamos muito preocupados, pensando que não o veríamos novamente." (p. 137)

c- "Os ricos do país costumavam aparecer nas férias, para aproveitar nosso ar limpo [...]" (p. 18)

d- "O tráfego na estrada mostrava-se cada vez mais pesado." (p. 135)

e- "Nossa nação ainda está cheia de estatísticas chocantes, e não só em educação." (p. 190)

f- "Depois, monitoraram a casa com uma espécie de drone gigante [...]" (p. 157)

É válido ressaltar que para o desenvolvimento da questão 4, o professor pode disponibilizar dicionários on-line através de links, de modo que os discentes tenham a oportunidade de pesquisarem os sinônimos. Sugere-se aqui, o uso do dicionário

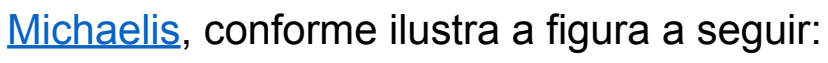


Figura 10- Dicionário Michaelis

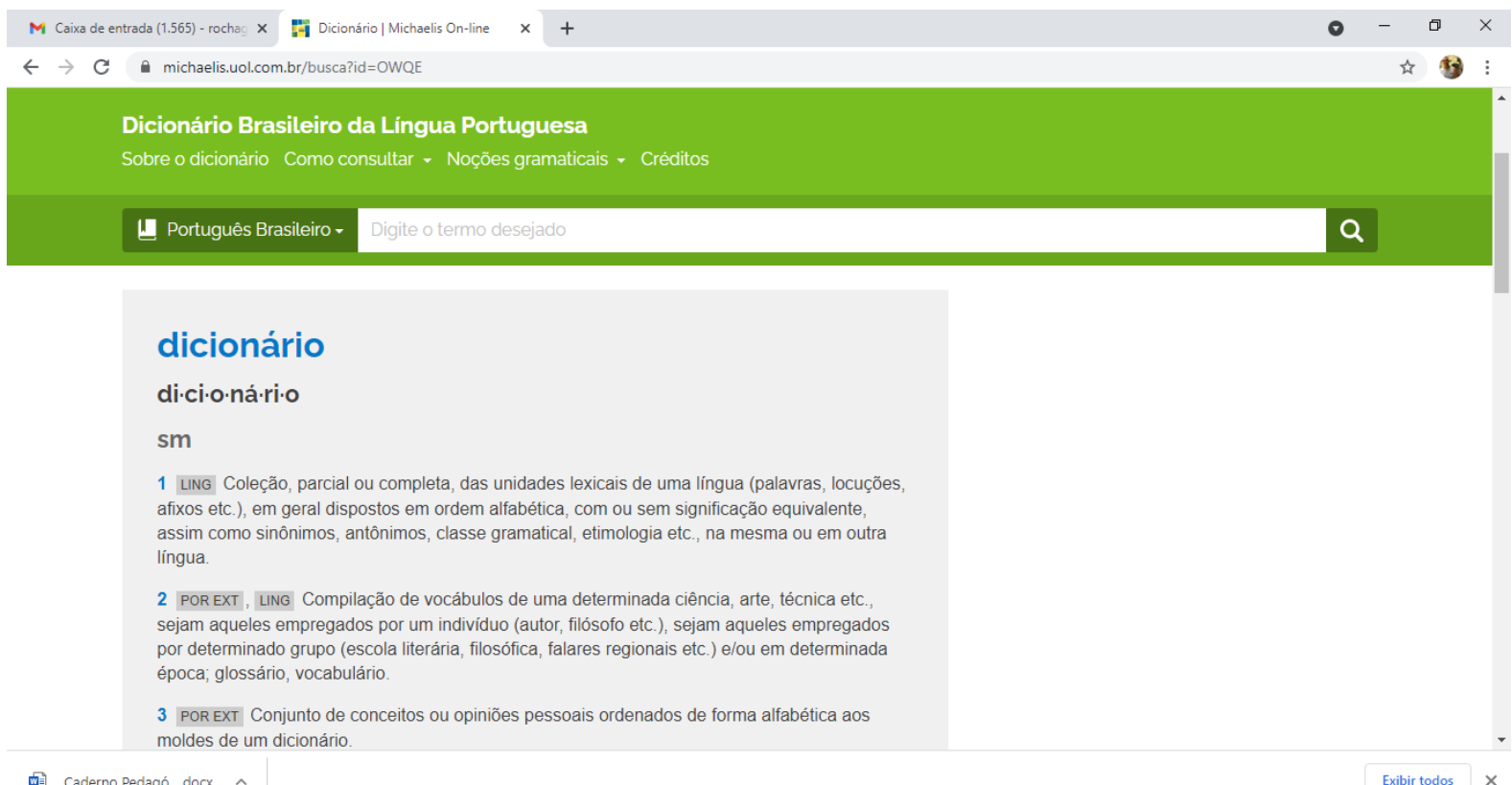

* $\rho$ Digite aqui para pesquisar

莒 w旦 $\odot$ 且 9

Fonte: https://michaelis.uol.com.br/busca?id=OWQE 


\section{Etapa 3: trabalhando a argumentação e diferenciando fato de opinião}

De forma a trabalhar, em termos mais específicos, a segunda parte da estrutura de um comentário crítico, propõe-se uma atividade enfatizando a argumentação de modo que os discentes tenham subsídios para justificar seus pontos de vista.

Ressalta-se aqui a proposta de inversão da sala de aula, ancorada em fundamentos da Flipped Classroom; dessa maneira, os alunos deverão assistir a um vídeo em casa, caso a atividade seja aplicada de forma presencial, ou em um momento assíncrono, se posta em prática no âmbito de uma aula remota. $\mathrm{O}$ vídeo está disponível no YouTube, e pode ser acessado aqui, como apresentado na imagem a seguir:

Figura 11- Vídeo sobre argumentação

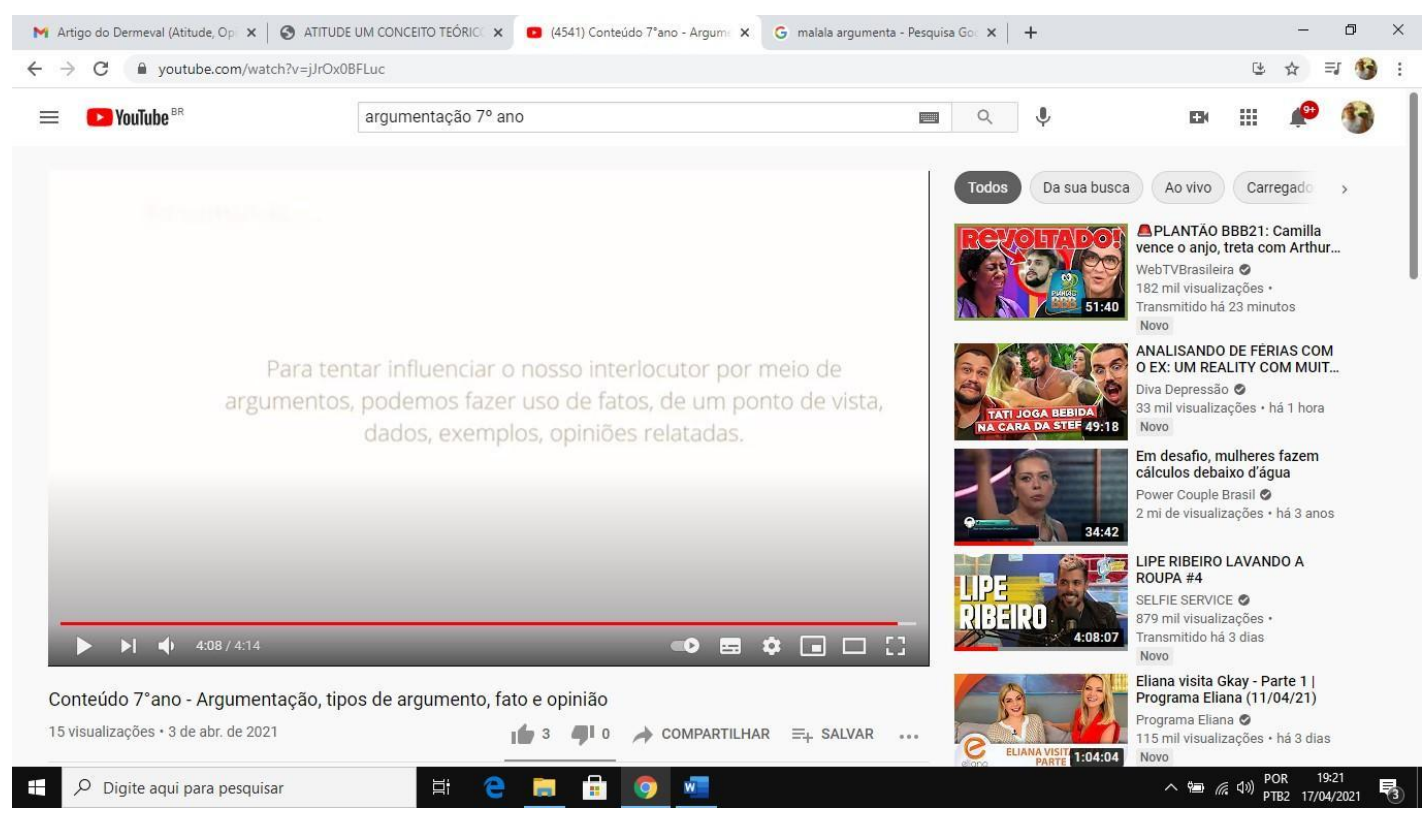

Fonte: https://www.youtube.com/watch?v=jJrOxOBFLuc

Em sala, ou durante o momento síncrono, o professor deverá proceder a uma discussão inicial acerca do vídeo assistido, para engajar os alunos no tema da aula e verificar as dúvidas. O docente poderá retornar ao assunto do vídeo argumentação - explicando pontos que possam ter causado dúvidas.

A seguir, propõe-se um roteiro de questões que podem ser utilizadas para consolidar o conteúdo do vídeo, através da discussão sobre Malala: 
1- Para cada uma das sentenças a seguir sobre Malala Yousafzai, diga se é um FATO ou OPINIÃO:

( ) Malala Yousafzai é a mais jovem premiada pelo Prêmio Nobel da Paz.

( ) O empoderamento das meninas vem da educação.

( ) Malala Yousafzai esteve no Brasil em 2018.

( ) Malala foi alvo de ataque a tiros por membros do Talibã.

( ) Livros e canetas são nossas armas mais poderosas.

( ) A jovem não pode viver em sua terra natal de forma permanente.

2- Através de seu slogan: "Livros, não balas", Malala apresenta um ponto de vista. Quais argumentos a ativista apresenta para sustentar sua tese?

3- O ponto de vista de Malala é o mesmo que o da maior parte da população paquistanesa? Justifique.

4- Que fato ocorreu para que Malala ficasse famosa em todo o mundo? Qual sua opinião sobre o ocorrido?

5- Na biografia de Malala, na página 10, ela compara seu antigo país ao seu atual local de residência, afirmando que "Meu país fica séculos atrás deste em que estou agora". Quais fatos a jovem apresenta para fazer essa afirmação?

6- Na sua opinião, a premiação de Malala Yousafzai foi justa? Por quê?

Como tarefa para o momento posterior à aula, os alunos deverão pesquisar duas pessoas de sua família (ou escolher entre seus amigos, fora do ambiente escolar), que conheçam um pouco sobre a vida de Malala Yousafzai e pedir que elas digam suas opiniões sobre a ativista. Os discentes deverão trazer, na aula seguinte, os resultados de sua tarefa anotados em seus cadernos, para compartilhá-los com a turma.

Na segunda aula da etapa 3, cujo objetivo é consolidar estruturas argumentativas e diferenciar fatos de opiniões, os alunos deverão recorrer às informações obtidas por meio dos registros da entrevista com amigos ou familiares. O docente poderá utilizar o momento inicial para perguntar como foram as entrevistas, se muitas pessoas de suas famílias conheciam ou já tinham ouvido falar sobre Malala, assim como checar caso algum aluno não realizou a atividade. 
Seguem abaixo algumas sugestões de perguntas para motivar a interação entre o professor e seus alunos:

1- As opiniões registradas por você após entrevistar dois de seus familiares ou amigos são iguais? Explique as diferenças entre elas.

2- Quais argumentos foram utilizados pelos seus entrevistados para defesa de seus pontos de vista?

3- Os argumentos apresentados pelos seus entrevistados foram baseados em fatos ou em crenças pessoais? Justifique.

4- Você concorda com os seus entrevistados? Justifique.

5- Em sua opinião, jovens foram beneficiados pelas palavras de Malala?

6- Se você tivesse a oportunidade de realizar um discurso assim como Malala teve, o que você defenderia? Por quê? 


\section{Etapa 4: (re)conhecendo o comentário crítico}

A tarefa inicial da aula consistirá, caso o ensino presencial seja restabelecido, em uma pesquisa por parte dos alunos, a ser realizada em casa, a respeito de textos do gênero comentário crítico, sem que seja solicitado a eles que façam exercícios previamente preparados, como ocorre em uma aula tradicional.

$O$ docente pode sugerir, por exemplo, que os alunos acessem o site AdoroCinema, disponível para acesso aqui, no qual é possível encontrar comentários críticos acerca dos mais diversos filmes e séries, conforme ilustra a imagem a seguir:

Figura 12 - Portal AdoroCinema

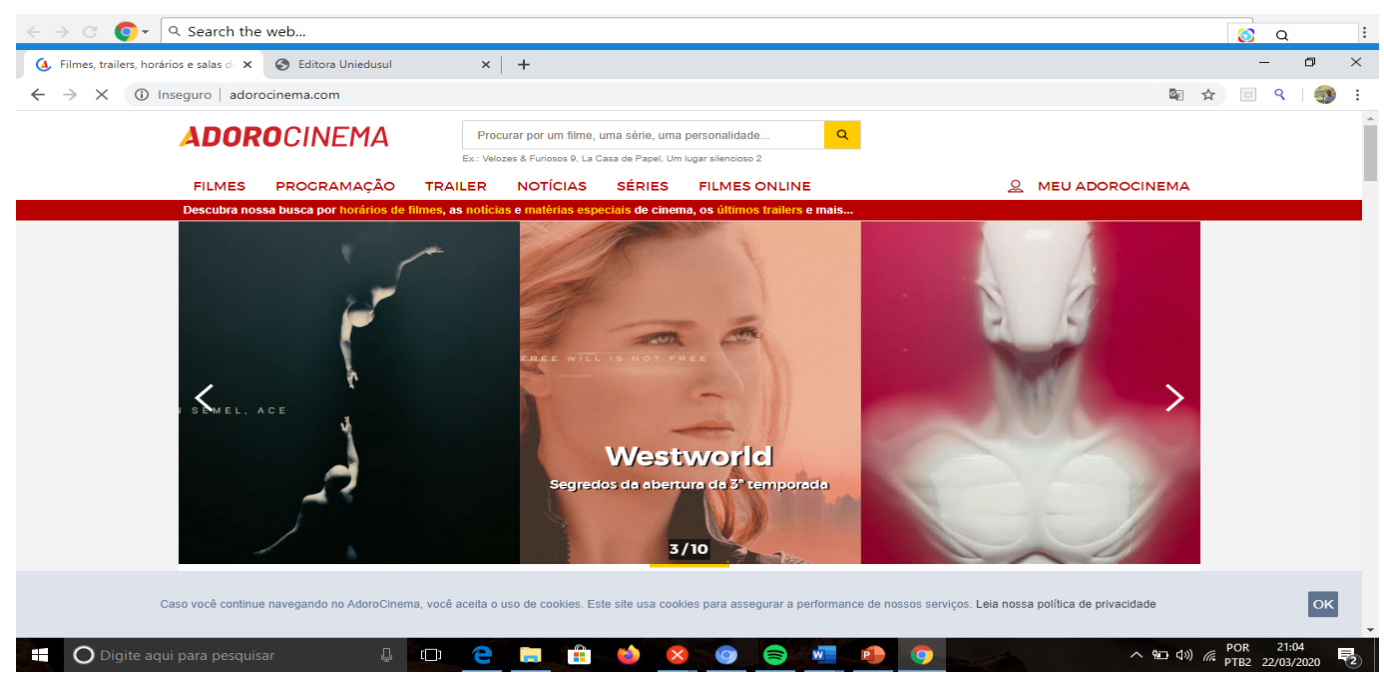

Fonte: Portal AdoroCinema

Posteriormente, um levantamento inicial acerca da compreensão geral do gênero pela turma será escrito no caderno, realizando-se esta atividade em duplas, tendo em vista a possibilidade de um ou outro aluno não ter feito a atividade de pesquisa em-casa, seja por dificuldade de acesso à Internet, seja pelo surgimento de dúvidas, ou ainda, por outros motivos de ordem particular. Esse trabalho poderá ser realizado individualmente, caso a atividade seja aplicada de maneira remota, ou em duplas e grupos. As perguntas a seguir são de compreensão geral sobre os comentários escolhidos pelos alunos e trazidos de casa para a aula:

- O que é um comentário crítico?

- Qual o principal objetivo de um comentário crítico? 
- O que é necessário ser realizado antes de escrever um comentário?

- Quais elementos um bom comentário precisa ter?

- Você posta comentários na Internet? Por quê?

- Onde é possível encontrar comentários, além de sites da Internet?

As perguntas deverão ser respondidas com o auxílio do professor, tendo como base as pesquisas realizadas em casa e as discussões do início da aula, em conformidade com a proposta da Sala de Aula Invertida. O docente poderá levar uma definição de comentário crítico como um suporte para os alunos que não tenham conseguido realizar a tarefa. Em relação à última pergunta, espera-se que os estudantes citem os comentários postados por leitores de jornais e revistas on-line, por exemplo. Os alunos deverão registrar suas respostas no caderno para posterior avaliação. 


\section{Etapa 5: elaborando um roteiro norteador}

Tendo em vista o principal objetivo do gênero e identificadas as dificuldades dos alunos, a etapa 6 do projeto interventivo será destinada a uma produção conjunta, um roteiro a ser trabalhado com os discentes em uma nova produção de comentário crítico, de forma a direcionarem mais apropriadamente suas produções. Para a contextualização do comentário, sugerem-se as seguintes questões norteadoras, tomando como base o livro "Eu sou Malala": qual o título da obra; quem publicou o livro e qual o ano de seu lançamento; quem é a protagonista (identificação do nome, país de origem, região onde vivia, idade em que sofreu o atentado, data do atentado).

Da mesma forma, para a constituição da apreciação crítica, as seguintes perguntas serão apresentadas: Com base nos trechos que lemos em aula, qual sua opinião sobre a obra "Eu Sou Malala"? O que Malala defendia? Como as fake news atribuídas à Malala a tornaram alvo do Talibã? Tendo em vista a última etapa estrutural do comentário crítico (a recomendação, ou não do livro), serão delineadas as seguintes questões norteadoras: Com base nos trechos lidos em aula, você recomendaria, ou não, a obra "Eu Sou Malala" a um amigo ou familiar? Justifique sua resposta.

É válido ressaltar que os alunos deverão ser estimulados a acrescentarem outras perguntas ao roteiro, de forma que o tornem mais contextualizado para a futura produção do comentário.

Caso a aula seja aplicada remotamente, sugere-se que o docente crie um arquivo Google Docs com vistas à produção colaborativa do roteiro. 


\section{Etapa 6: escrevendo e avaliando um comentário}

Propõe-se que, na etapa 6 da SD, com vistas à consolidação do papel ativo do discente, a aula seja iniciada com uma conversa acerca da obra "Eu sou Malala", incentivando que os alunos emitam oralmente suas opiniões. $O$ docente pode questionar se eles conhecem outras figuras femininas que sejam consideradas marcantes pelos seus feitos e encorajá-los a buscarem mais informações para compartilharem com seus pares. Sugere-se aqui a história de Maya Angelou, narrada em sua biografia "Eu sei por que o pássaro canta na gaiola", cujo e-book encontra-se disponível para download aqui e a obra "Contra o Fanatismo", de autoria de $\mathrm{Amos} \mathrm{Oz}$, cujo compilado em pdf está disponibilizado aqui.

Posteriormente, os alunos deverão escrever um comentário, abarcando as três partes essenciais do comentário crítico: apresentação do tema da obra, apreciação crítica do conteúdo, seguindo-se a argumentação e o desfecho, com recomendação do livro, ou não.

As respostas obtidas nesta etapa serão escritas pelos alunos em uma folha separada. Após a produção escrita, o professor deverá recolher os textos e redistribuí-los aleatoriamente, de forma que cada discente tenha acesso ao texto de outro colega. Logo em seguida, o professor deverá orientar os alunos acerca dos critérios para a revisão de textos, os quais se encontram descritos no quadro a seguir, que será compartilhado com discentes no dia da aula síncrona:

\section{Quadro 1 - Critérios avaliativos dos comentários críticos}

\begin{tabular}{|l|l|l|l|}
\hline $\begin{array}{l}\text { Critérios para a } \\
\text { revisão de textos }\end{array}$ & $\begin{array}{l}\text { O comentário é } \\
\text { introduzido através } \\
\text { da apresentação do } \\
\text { tema do livro? }\end{array}$ & $\begin{array}{l}\text { O comentário } \\
\text { apresenta elogios ou } \\
\text { críticas seguidas por } \\
\text { argumentos, } \\
\text { embasados no livro } \\
\text { lido? }\end{array}$ & $\begin{array}{l}\text { O comentário é } \\
\text { finalizado com } \\
\text { recomendação } \\
\text { positiva ou negativa } \\
\text { do livro? }\end{array}$ \\
\hline $\begin{array}{l}\text { Sim, e de maneira } \\
\text { clara e satisfatória }\end{array}$ & & & \\
\hline $\begin{array}{l}\text { Sim, porém com } \\
\text { problemas de } \\
\text { clareza e de } \\
\text { maneira insuficiente }\end{array}$ & & & \\
\hline Não apresenta & & & \\
\hline
\end{tabular}

Fonte: Machado et al. 2004 
Após os alunos procederem à avaliação escrita dos textos, uns dos outros, tomando como base os critérios acima explicitados, as avaliações serão recolhidas pelo professor, assim como os comentários, para que sejam devolvidos a seus autores. Ao final da aula, o docente poderá questionar se eles concordam, ou não, com as avaliações recebidas e pedirá que eles justifiquem oralmente seu posicionamento. Tendo em vista o objetivo final da produção dos comentários críticos, que é a construção de uma seção cultural do jornal da escola para divulgação futura desses comentários, o professor recolherá novamente os textos para uma última correção dessas produções textuais, a fim de ajustar inadequações quanto a aspectos formais que os alunos possam não dominar e, por isso, não ter identificado. Os problemas verificados poderão ser trabalhados em aulas voltadas à ao estudo de conteúdos relacionados à norma-padrão, buscando-se contextualizar a análise linguística. Sem dúvida, este é um desafio às metodologias ativas de aprendizagem, pois, nesse caso, a sistematização é parte necessária para a consolidação do conhecimento da variante de prestígio social, tarefa da escola. 


\section{Etapa 7: produzindo uma seção cultural}

A produção final dessa SD consistirá na construção conjunta de uma seção cultural do jornal da escola, que poderá ser divulgado de maneira impressa, caso as aulas estejam ocorrendo de maneira presencial, ou em formato de e-book. A seção supracitada apresentará os comentários produzidos pelos alunos sobre a obra "Eu Sou Malala", produzidos na etapa 6. Nos comentários, eles deverão realizar uma apreciação crítica de trechos da obra, dizendo se gostaram ou não, apresentando justificativa embasada em elementos do próprio livro e recomendação, ou não, conforme estrutura apresentada na etapa 6.

Sugere-se que, além dos comentários acerca da biografia de Malala Youszafai, o docente estimule que os alunos mencionem livros, filmes, curtas ou séries de que gostem, de modo a criar uma lista de sugestões para os demais alunos da escola. Como proposta a lista pode ser acrescentada dentro da seção cultural em uma das extremidades do arquivo com o título: "O que a turma $\mathrm{X}$ recomenda aos alunos da turma Y?"

O docente que desejar, poderá acessar aqui um tutorial de como diagramar um jornal através do Word. Ele poderá dividir as tarefas para a edição e publicação do jornal, tais como: criar um grupo de alunos que tenham facilidade com programas de edição, os quais ficarão responsáveis por organizar a diagramação dos comentários no formato da uma seção cultural, enquanto outro grupo ficará responsável pela divulgação nas redes sociais. 


\section{Encerrando a conversa}

Recapitulando o que já se mencionou, os comentários escritos pelos alunos na etapa 6 , após passarem por uma revisão inicial realizada pelos próprios alunos, com base nos critérios do Quadro 2, serão corrigidos pelo professor e, posteriormente, devolvidos a seus autores, para que realizem as correções apontadas. O docente mediará, portanto, a produção da etapa final da Sequência Didática, que consiste na confecção de uma seção cultural para o jornal da escola.

Espera-se que este projeto interventivo contribua no sentido de promover práticas ativas de aprendizagem no âmbito da educação básica, estimulando discentes a desenvolverem suas competências argumentativas através de comentários críticos que apresentem apreciações críticas fundamentadas. Como o aluno deverá se preparar previamente em relação ao conteúdo a ser trabalhado em cada etapa da intervenção, um dos benefícios mais importantes da Sala de Aula Invertida é, sem dúvidas, a possibilidade de promover debates mais ricos e produtivos em sala de aula, viabilizando-se a discussão da aplicabilidade desse conhecimento em situações reais e práticas da vida desses alunos. 


\section{Referências e sugestões de leitura}

ANTUNES, Irandé. Aula de português: encontro \& interação. 8 ed. São Paulo: Parábola Editorial, 2009.

ANTUNES, Irandé. Gramática contextualizada: limpando "o pó das ideias simples". São Paulo: Parábola Editorial, 2014.

ANTUNES, Irandé. Muito além da gramática: por um ensino de línguas sem pedras no caminho. $4^{a}$ ed. São Paulo: Parábola Editorial, 2007.

BERGMANN, Jonathan; SAMS, Aaron. Sala de aula invertida: uma metodologia ativa de aprendizagem. Rio de Janeiro: LTC, 2016.

COSTA-HÜBES, T.C.; SIMIONI, C.A. Sequência didática: uma proposta metodológica curricular de trabalho com os gêneros discursivos/ textuais. In:

BARROS, E. M. D.; RIOS-REGISTRO, E. S. (Org.). Experiências com sequências didáticas de gêneros textuais. Campinas: Pontes Editores, 2014.

DOLZ, J.; NOVERRAZ, M.; SCHNEUWLY, B. Sequências didáticas para o oral e a escrita: apresentação de um procedimento. In: SCHNEUWLY, B.; DOLZ, J. Gêneros orais e escritos na escola. [Tradução e organização de Roxane Rojo e Glaís Sales Cordeiro]. Campinas, SP: Mercado de Letras, 2004. p. 95-147

MACHADO, Anna Rachel; LOUSADA, Eliane; ABREU-TARDELLI, Lilia Santos. Resenha. São Paulo: Parábola, 2004.

MAGALHÃES, T. G. \& CRISTOVÃO, V. L. L. Sequências e projetos didáticos no Pacto Nacional pela Alfabetização na Idade Certa: uma leitura. Campinas/SP: Pontes Editores, 2018.

MATTAR, João. Metodologias ativas para a educação presencial, blended e a distância. São Paulo: Artesanato Educacional, 2017.

PINTON, Francieli Matzenbacher; STEINHORST, Camila; BARRETO, Taís. Glossário de gêneros e suportes textuais: Base Nacional Comum Curricular. Universidade Federal de Santa Maria, 2020 


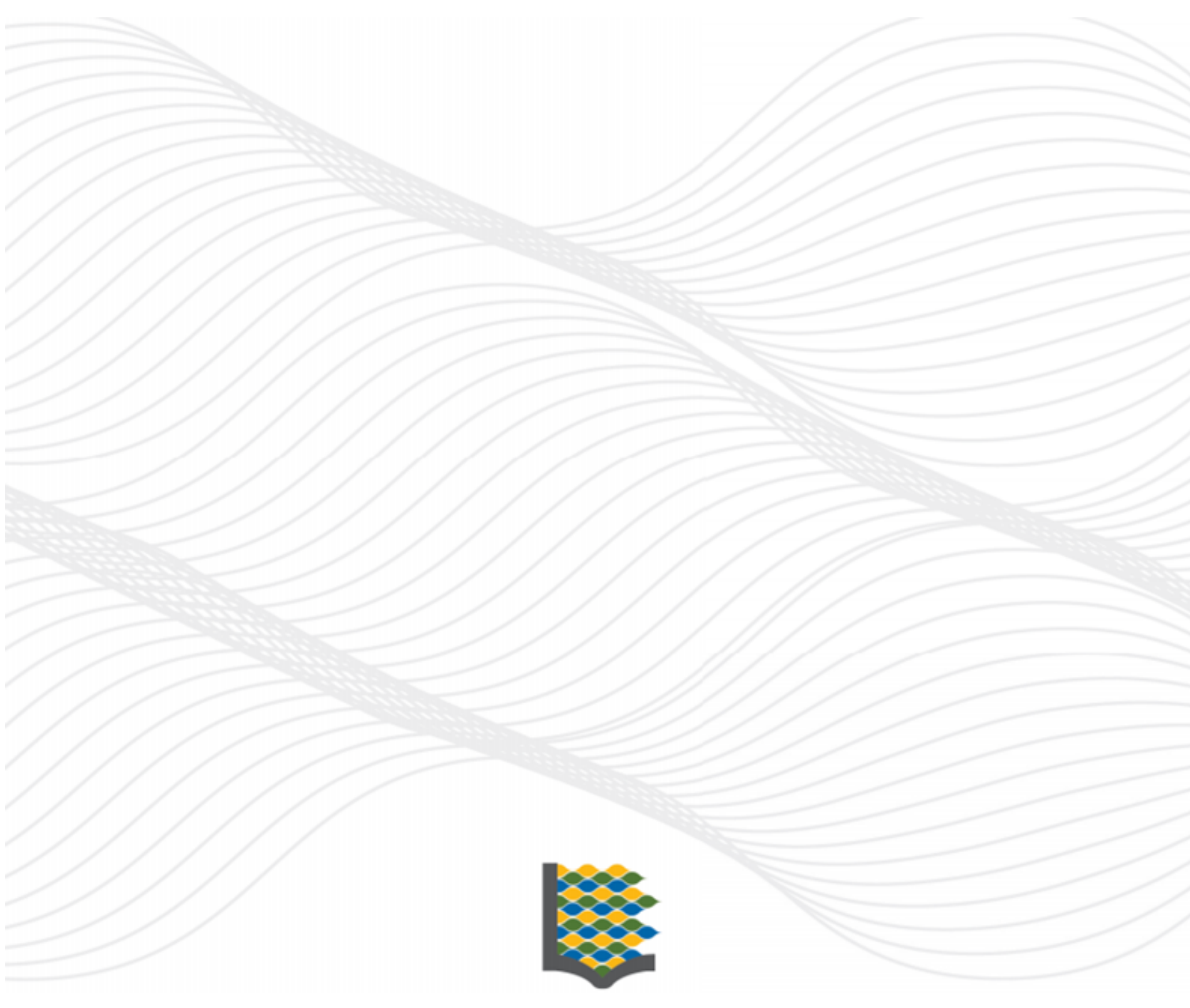

